\title{
Ways Of Development Of Small Business Enterprises In The Republic Of Uzbekistan
}

\author{
Abdulxakimov Zuhrali Tursunalievich \\ Senior Lecturer, Namangan Institute of Engineering and Technology, Republic of \\ Uzbekistan, Economics Doctor of Philosophy (PhD), \\ Ergashev Jamshid Jamoliddinovich \\ Senior Lecturer, Namangan Institute of Engineering and Technology \\ Abdul Rahmat \\ Gorontalo State University Indonesia \\ abdulrahmat@ung.ac.id
}

Received: 02 Oktober 2020; Revised: 21 November 2020; Accepted: 28 Desember 2020 DOI: http://dx.doi.org/10.37905/aksara.7.1.137-146.2021

\begin{abstract}
This article examines the activities of small businesses in the Republic of Uzbekistan and the profound structural changes during the pandemic and their impact on the economy. Keywords: World economy, Covid-19, globalization, GDP, small business, digital economy.
\end{abstract}

\section{Introduction}

At the beginning of the XXI century, the economy of the Republic of Uzbekistan has achieved a steady pace of development. Global changes in the world economy, the tightening of relations between many countries have had an impact on the level of economic development in the regions of the country. Today, domestic and foreign economic research consists of the active development of new models of economic development. In order to achieve sustainable economic development, it is necessary to make full use of the achievements of the Fourth Industrial Revolution, to raise the sectors of the economy to the fifth and sixth technological sectors.

And family businesses are gaining a strong foothold in the world economy. "The share of family companies in the European Union is 50\%, in Latin America - 65-90\%, in the United States - 95\%. In addition, $45-50 \%$ of the GDP of European countries, $70 \%$ of Latin American countries, and 65-82\% of the GDP of Asian countries are created by family enterprises "[40]. In the modern world economy, small business and private entrepreneurship play an important role in the development of the economy, employment, poverty reduction in the regions of the country, self-employment. The mass economic interests of many segments of the population are also mainly focused on small businesses [39]. The share of small business and private entrepreneurship in the GDP of many countries is high. 
In recent years, small business and private entrepreneurship, as a rapidly adapting sector of the economy, play an important role in filling the domestic market with consumer goods, expanding new and modern types of services, developing export potential. Therefore, special attention was paid to the rapid development, promotion and support of small business and private entrepreneurship, which play an increasingly important role in ensuring economic growth, creating new jobs, solving the problem of employment, increasing incomes and welfare of the population.

Main part. Strengthening the level of development of small business in the Republic of Uzbekistan, and through the establishment of small enterprises to provide great opportunities for small business and private entrepreneurship in the country's economy. This includes employment of the population, elimination of unemployment and the development of new areas of small business development in the period of the coronavirus pandemic "COVID-19", which began in the first quarter of 2020, the development of small businesses adapted to the digital economy. It is necessary to accelerate the implementation of the achievements of the Fourth Industrial Revolution through the widespread application of the principles of "Industry 4.0" in small business and private entrepreneurship, as in all sectors. It is necessary to create a new system of innovative small business and private entrepreneurship, compatible with the digital economy, based on innovation from traditional production in all sectors of the economy. Independent business owners were formed. It is a priority for small businesses to be able to adapt to the various macroeconomic conditions and requirements inherent in a market economy.

The development of small business and private entrepreneurship in various sectors of the economy is one of the important macroeconomic factors in ensuring the stability of the national economy. This can be explained by the growing share of small businesses in the country's GDP as a result of the rapid growth of small businesses in recent years. The country's economic development program will pay special attention to the rapid development, promotion and support of small business and private entrepreneurship, which play an increasingly important role in ensuring economic growth, creating new jobs, solving the problem of employment, increasing incomes and welfare of the population.

\section{Results and discussion}

According to the results of research conducted in our country, it is necessary to take into account the specifics of the country's regions in the development of small business and private entrepreneurship. The support provided by the state is leading to significant structural changes in the industry. In our opinion, it is necessary to create conditions for small business and private entrepreneurship in the regions of the country, to form a reliable legal framework for them, to increase their efficiency and transparency at all levels, to increase the attractiveness of investment activities.

The main feature of small business and private entrepreneurship is that for it, regional factors, as a rule, prevail in terms of their impact on the process of attracting investment. It should be noted that the analysis of the investment climate should be conducted by industry. Because positive investment factors have specific aspects for different industries. In some cases, the factors that can play a positive role in one network will be negative for another network, or if any indicator for a particular network is 
sufficiently visible, this indicator itself may be absolutely low for the successful development of another network. Of particular interest in Uzbekistan is the investment climate by sector for small business and private entrepreneurship.

For small business and private entrepreneurship you will need to list some specific features:

- The system of state support and development mechanisms for the development of small businesses and private entrepreneurship;

- creation of opportunities for small and medium enterprises together with large enterprises operating in the occupied market sectors;

-Determine the specifics of small business and private entrepreneurship specific to each region and suggest the appropriate types of activities.

Based on the specifics of small business and private entrepreneurship, it is advisable to attract investment in targeted areas. It should be noted that in small business and private entrepreneurship it is necessary to take into account the possibility of selfinvestment, depending on the internal capacity of each region. The use of these opportunities in small business and private entrepreneurship is able to provide significant benefits and has a number of advantages in terms of the effectiveness of the attraction. Thus, it is necessary to increase the number of favorable opportunities for the formation of investment resources and increase the efficiency of the use of available resources, to frequently update and redesign the mechanisms of state support for small business and private entrepreneurship.

One of the important features of small business and private entrepreneurship is the ability to operate more efficiently and effectively than investments than large firms, making efficient use of any non-large investment. The reason for this feature is that, first of all, small business and private entrepreneurship will not need large investments, will be able to quickly adapt to changes in markets, to operate without interruptions in any economic crisis.

In this regard, measures are being taken to create favorable conditions for the development of small business and private entrepreneurship in the economy of the Republic of Uzbekistan and to improve the working environment. The process of finding, attracting and putting financial investments into production to carry out the development of the sector will always be more formalized and regulated by normative documents in order to further enhance these achievements, at least to keep them in such a positive position. In this regard, it is expedient to attract innovations to the industry through the use of intellectual technologies. Small businesses and private entrepreneurs do not have the necessary funds to purchase finished products, but it is necessary to focus investment mainly on innovation in the industry. Leasing and franchising are widely used among various forms of attracting material investment in a number of countries implementing market reforms. In addition, mechanisms for state support of small business and private entrepreneurship have been developed. The level of development of special regulatory frameworks governing the attraction of investment in the development of small business and private entrepreneurship in the regions will ensure the development of appropriate market infrastructure. 


\section{Conclusions}

The main feature of small business and private entrepreneurship is the creation of a small business and private entrepreneurship industry that is low-cost and quick to adapt to market requirements in any situation. The organization of such an industry involves the introduction of digital technologies. Therefore, it is necessary to develop digital platforms suitable for each industry.

1. Ensuring employment, overcoming the problem of unemployment and developing new directions for the development of small business during the coronavirus pandemic "COVID-19", which began in the first quarter of 2020;

2. 2.Development of small business areas adapted to the digital economy, implementation of the achievements of the fourth industrial revolution through the widespread application of the principles of "Industry 4.0" in the field of small business and private entrepreneurship;

3. Creation of a new innovative system of small business and private entrepreneurship, compatible with the digital economy, based on innovations from traditional production in all sectors of the economy;

4. Analysis of important macroeconomic factors to ensure the stability of the national economy, the development of small business and private entrepreneurship in various sectors of the economy of Uzbekistan;

5. To study the factors influencing the planning of small business and private entrepreneurship in the digital economy, the statistical database, the issues of optimal technical approach, the supply and demand base for investment projects, the deployment of innovative ideas;

6. It is expedient to develop the activities of new professions through the widespread use of digital technologies. It is necessary to develop freelance activities in this area;

7. In the development of households in the digital economy, first of all, the introduction of new forms of small business in the economy, the development of facilities based on digital systems, the ability to receive high salaries, efficient distribution of working time, mainly in a virtual state operation is ensured;

In short, measures aimed at creating a favorable working environment will increase the contribution of small business to economic growth, create new jobs and make qualitative changes in other important sectors of the economy.

\section{References}

Action Strategy on the five priority areas of development of the country for 2017-2021, provided by the Decree of the President of the Republic of Uzbekistan dated February 7, 2017 "On the Action Strategy for further development of the Republic of Uzbekistan".-T .: Uzbekistan, 2017

Тухтасинова, Д. Р. (2019). ТЕОРИТИЧЕСКИЕ ОСНОВЫ СОВЕРШЕНСТВОВАНИЯ ТЕХНОЛОГИИ АНТИКРИЗИСНОГО УПРАВЛЕНИЯ НА ПРЕДПРИЯТИЯХ. АПробация, (4), 77-79.

.Тухтасинова, Д. Р. (2018). ИННОВАЦИЯ И МОДЕРНИЗАЦИЯ ЭКОНОМИКИ. In РОЛЬ ЧЕЛОВЕЧЕСКОГО КАПИТАЛА В СОЦИАЛЬНОЭКОНОМИЧЕСКОМ РАЗВИТИИ (рр. 124-127). 
.Муминова, Э. А., \& Тухтасинова, Д. Р. (2016). The problems of financingenterprises in the condition of innovative activity. Символ науки, (12-1).

Muminova, Elnorakhon and Tukhtasinova, Dildora (2019) "THE ISSUES OF DEVELOPMENT OF FINANCING OF INVESTMENT PROJECTS BY COMMERCIAL BANKS," Scientific Bulletin of Namangan State University: Vol. 1 : Iss. 8 , Article 23. Available at: https://uzjournals.edu.uz/namdu/vol1/iss $8 / 2$

Dodxomirzaevich, S. S., Mamadjanovich, Y. K., \& Axrorbek, M. (2020). A REVIEW ON FUSION OF DIFFERENT DEFOGGING TECHNIQUES TO CLEAR IM IMPROVING PRIVATE EDUCATION SERVICE IN PUBLICPRIVATE PARTNERSHIP. International Engineering Journal For Research \& Development, 5(Special Issue), 6-6.

Юлдашев, К. М., \& Холмирзаев, А. Х. (2019). Осуществление реализации механизма частного партнерства в Узбекистане. Молодой ученый, (51), 435-437.

Tursunalievich, A. Z. (2020). ESTABLISHMENT AND USE OF SMALL ECO-ZONES IN THE DEVELOPMENT OF RECREATIONAL ACTIVITIES. International Engineering Journal For Research \& Development, 5(Special Issue), 7-7.

Ikromjonovna, I. N., Abdulaxad, S., \& Tursunalievich, A. Z. (2020). ESTABLISHMENT OF AGRICULTURAL CLUSTERS IN AGRICULTURE. International Engineering Journal For Research \& Development, 5(Special Issue), 8-8.

Abduganievich, A. U., Bakhriddinovich, I. R., \& Tursunalievich, A. Z. (2020). DEVELOPMENT OF PHYSICAL TRAINING AND SPORTS IN THE REPUBLIC OF UZBEKISTAN. International Engineering Journal For Research \& Development, 5(Special Issue), 8-8.

Abduganievich, A. U., Bakhriddinovich, I. R., \& Tursunalievich, A. Z. (2020). DEVELOPMENT OF PHYSICAL TRAINING AND SPORTS IN THE REPUBLIC OF UZBEKISTAN. International Engineering Journal For Research \& Development, 5(Special Issue), 8-8.

Tursunalievich, A. Z., \& Bakturdievich, I. E. (2020). TREATMENT AND REHABILITATION OF TOURISM AND RECREATION. International Engineering Journal For Research \& Development, 5(Special Issue), 8-8.

Abdurashidovich, B. D., Bakhriddinovich, I. R., Tursunalievich, A. Z., \& Zokirjonovich, K. Q. (2020). ISSUES OF SMALL BUSINESS AND PRIVATE ENTREPRENEURSHIP DEVELOPMENT. International Engineering Journal For Research \& Development, 5(Special Issue), 7-7.

Ismoilov, R. B., Mullabayev, B. B., \& Abdulxakimov, Z. T. (2020). Prospects For The Development Of A Tourist Route" Safed Broth Or Horn Jarir". The American Journal of Interdisciplinary Innovations and Research, 2(08), 38-44.

Ismoilov, R. B., Mullabayev, B. B., Abdulxakimov, Z. T., \& Bakhriddino, J. R. O. (2020). The Essence Of Small Business And Private Entrepreneurship And The Theoretical Basis Of Its Development. The American Journal of Applied sciences, 2(08), 45-50. 
Aliyev, Y. (2020). МИНТАҚАВИЙ ТУРИСТИК-РЕКРЕАЦИОН МАЖМУАЛАРНИ ТАШКИЛ ЭТИШДА ДАВЛАТ-ХУСУСИЙ ШЕРИКЧИЛИК ТИЗИМИНИ РИВОЖЛАНТИРИШ. Архив научных исследований, (19).

Tursunalievich, A. Z. (2019). Senior Teacher of the Namangan Engineering and Technology Institute. Scientific and analytical journal «Science and Practice» of Plekhanov University, 11(1), 33.

Abdulxakimov, Z. T., \& Raxmonjonov, R. S. (2019). ATTRACTING INVESTMENTS TO THE ECONOMY. Priorities for ensuring the economic security of the country, 1(4), 3.

Abdulhakimov, Z. T. (2018). Establishment of tourism and recreational facilities and recreational facilities in Namangan region. Economics and Innovative Technologies, 2018(4), 15.

Bakhriddinovich, I. R., Bulturbayevich, M. B., Gulomjanovna, M. N., \& Karimjanovich, U. R. (2020). USE OF MODERN MARKETING RESEARCH IN THE CONTEXT OF MARKET DEVELOPMENT. International Engineering Journal For Research \& Development, 5(Special Issue), 8-8.

Abdurashidovich, B. D., Bakhriddinovich, I. R., \& Bulturbayevich, M. B. (2020). THE STATE OF DEVELOPMENT OF SMALL BUSINESS AND PRIVATE ENTREPRENEURSHIP DURING THE CORONAVIRUS PANDEMIC. International Engineering Journal For Research \& Development, 5(Special Issue), 8-8.

Abduganievich, A. U., Bakhriddinovich, I. R., \& Bulturbayevich, M. B. (2020). CURRENT SITUATION OF INVESTMENT IN THE NATIONAL ECONOMY. International Engineering Journal For Research \& Development, 5(Special Issue), 7-7.

Bulturbayevich, M. B., Saodat, S., \& Shakhnoza, N. (2020). INNOVATIVE ACTIVITY OF SMALL BUSINESSES IS AN IMPORTANT TOOL FOR CREATING PRODUCTIVE JOBS. International Engineering Journal For Research \& Development, 5(6), 9-9.

Ismoilov, R. B., \& Matkarimov, K. Zh., Khaidarov Kh. Kh., Nabotova Z. THE ROLE OF THE TEACHER IN THE EDUCATIONAL PROCESS: ADDRESSED TRAINING OF SPECIALISTS OF SECONDARY PROFESSIONAL EDUCATION IN THE PROCESS OF NETWORK INTERACTION. materials of the IV All-Russian scientific-practical conference with international participation. Institute for the Development of Territorial Systems of Professional Education, 167-174.

Ergashev Jamshid Jaliddinovich,. (2020). PECULIARITIES OF SMALL BUSINESS AND PRIVATE ENTREPRENEURSHIP DEVELOPMENT IN UZBEKISTAN. International Engineering Journal For Research \& Development, 5(6), 10. https://doi.org/10.17605/OSF.IO/QK79M

Shermatov, A., \& Isakova, N. I. (2020). Development Of The Organization Of AgroCluster Activities In Agriculture. The American Journal of Management and Economics Innovations, 2(09), 17-29.

Bakhriddinovich, I. R., Bulturbayevich, M. B., Gulomjanovna, M. N., \& Karimjanovich, U. R. (2020). USE OF MODERN MARKETING RESEARCH IN THE 
CONTEXT OF MARKET DEVELOPMENT. International Engineering Journal For Research \& Development, 5(Special Issue), 8-8.

Abdurashidovich, B. D., Bakhriddinovich, I. R., \& Bulturbayevich, M. B. (2020). THE STATE OF DEVELOPMENT OF SMALL BUSINESS AND PRIVATE ENTREPRENEURSHIP DURING THE CORONAVIRUS PANDEMIC. International Engineering Journal For Research \& Development, 5(Special Issue), 8-8.

Abduganievich, A. U., Bakhriddinovich, I. R., \& Bulturbayevich, M. B. (2020). CURRENT SITUATION OF INVESTMENT IN THE NATIONAL ECONOMY. International Engineering Journal For Research \& Development, 5(Special Issue), 7-7.

Bulturbayevich, M. B., Saodat, S., \& Shakhnoza, N. (2020). INNOVATIVE ACTIVITY OF SMALL BUSINESSES IS AN IMPORTANT TOOL FOR CREATING PRODUCTIVE JOBS. International Engineering Journal For Research \& Development, 5(6), 9-9.

Bulturbayevich, M. B., \& Jurayevich, M. B. (2020). THE IMPACT OF THE DIGITAL ECONOMY ON ECONOMIC GROWTH. International Journal of Business, Law, and Education, 1(1), 4-7.

Mullabaev, B. B. (2018). ECONOMETRIC ANALYSIS OF VERTICAL INTEGRATION OF THE LIGHT INDUSTRY ENTERPRISES OF THE NAMANGAN REGION (ON THE EXAMPLE OF THE REPUBLIC OF UZBEKISTAN). Scientific Review: Theory and Practice,(8), 22, 36.

Mullabayev, B. B. (2018). Economic analysis of vertical integration integration of the Namangan region (on the prerogative of the Republic of Uzbekistan). Science of theory: theory and practice"-8.

Bachtijarzhan, M. (2017). DEVELOPMENT OF LIGHT INDUSTRY BRANCHES IN UZBEKISTAN BASED ON VERTICAL INTEGRATION. Бюллетень науки и практики, (10 (23)).

Abdulxakimov Zuhrali Tursunalievich, \& Saydalieva Umidhon Solijon qizi. (2020). ESTABLISHMENT AND USE OF SMALL ECO-ZONES IN THE DEVELOPMENT OF RECREATIONAL ACTIVITIES. International Engineering Journal For Research \& Development, 5(Special Issue), 7. https://doi.org/10.17605/OSF.IO/XN79M

Abdukakhorov Ulugbek Abduganievich, Ismoilov Ravshanjon Bakhriddinovich, Abdulxakimov Zuhrali Tursunalievich, \& Bakhriddinov Jahongir Ravshanjon ogli. (2020). DEVELOPMENT OF PHYSICAL TRAINING AND SPORTS IN THE REPUBLIC OF UZBEKISTAN. International Engineering Journal For Research \& Development, 5(Special Issue), 8. https://doi.org/10.17605/OSF.IO/W6E72

Isakova Naima Ikromjonovna, Shermatov Abdulaxad, \& Abdulxakimov Zuhrali Tursunalievich. (2020). ESTABLISHMENT OF AGRICULTURAL CLUSTERS IN AGRICULTURE. International Engineering Journal For Research \& Development, 5(Special Issue), 8. https://doi.org/10.17605/OSF.IO/Q94EK

Abdulxakimov Zuhrali Tursunalievich, \& Ibadullaev Ergash Bakturdievich. (2020). TREATMENT AND REHABILITATION OF TOURISM AND 
RECREATION. International Engineering Journal For Research \& Development, 5(Special Issue), 8. https://doi.org/10.17605/OSF.IO/JCNUW Gorfinkel V.Ya. Small business: study guide - M .: KHOPYC, 2009, 5-8 p. https://cyberleninka.ru/article/n/semeynoe-predprinimatelstvo-analiz-rossiyskoypraktiki 